\title{
Steroid 21-Hydroxylase
}

National Cancer Institute

\section{Source}

National Cancer Institute. Steroid 21-Hydroxylase. NCI Thesaurus. Code C40071.

Steroid 21-hydroxylase (494 aa, $\sim 56 \mathrm{kDa}$ ) is encoded by the human CYP21A2 gene. This protein plays a role in steroid hydroxylation. 